\title{
Análise faciológica e contexto deposicional do geossítio Bacia Sedimentar de Curitiba, nova seção-tipo para a Formação Guabirotuba
} Facies analysis and depositional context of the Curitiba Sedimentar Basin geosite: new type section to Guabirotuba Formation

\author{
Kimberlym Tábata Pesch Vieira ${ }^{1}$ (D), Luiz Alberto Fernandes ${ }^{1}$ (i) \\ 1 Universidade Federal do Paraná - UFPR, Programa de Pós-Graduação em Geologia, Setor de Ciências da Terra, Avenida Coronel \\ Francisco Heráclito dos Santos, 210, Jardim das Américas, CEP 81531-980, Curitiba, PR, BR (pesch@ufpr.br; lualfernandes@ufpr.br)
}

Recebido em 8 de janeiro de 2020; aceito em 12 de junho de 2020

\begin{abstract}
Resumo
O geossítio Bacia Sedimentar de Curitiba é um afloramento da Formação Guabirotuba, unidade que preencheu a Bacia de Curitiba, em área urbanizada. O sítio, localizado na região industrial da capital do Paraná, ganhou notoriedade por ser berço das ocorrências fossilíferas da Fauna Guabirotuba, uma das poucas representantes do Paleógeno no país, que permitiu estabelecer a idade relativa para o preenchimento da bacia. A análise faciológica do afloramento teve o objetivo de refinar o conhecimento acerca dos depósitos sedimentares da unidade, almejando contribuir para futuros estudos tafonômicos e paleoambientais. Para tanto, utilizaram-se métodos de análise faciológica em três segmentos representativos do afloramento, nos quais foram reconhecidas fácies sedimentares, elementos arquitetônicos, modificações eodiagenéticas (calcretes) e o contato com o embasamento. A caracterização composicional dos sedimentos foi complementada com análises petrográficas. O contexto deposicional da Formação Guabirotuba foi interpretado como de depósitos de canais e planícies de inundação de rios entrelaçados em sistema fluvial distributário. As associações de areias e cascalhos em barras que preencheram feições acanaladas foram consideradas como correspondentes a porções proximais, em que predominam depósitos de canais amalgamados, com avulsões frequentes. Esses depósitos ocorrem intercalados com associações de lamas, lençóis e lentes arenosas, caracterizadas como depósitos de espraiamentos laterais em porções distais do sistema. Nos cortes que compõem o afloramento foram feitas importantes descobertas fossilíferas nos últimos anos. Esse foi um dos motivos que tornaram a área unidade de conservação protegida por decreto municipal. Considerando-se tais novidades, e o fato de a seção original da Formação Guabirotuba ter sido ocultada pela urbanização, propõe-se designar o afloramento como área-tipo e o conjunto de seções como nova seção-tipo da unidade.
\end{abstract}

Palavras-chave: Bacia de Curitiba; Rift Continental do Sudeste do Brasil; Paleógeno.

\begin{abstract}
The Curitiba sedimentary Basin geosite is an outcrop of the Guabirotuba Formation, a unit that fills the Curitiba Basin, in an urbanized area. The site, located on the capital of Paraná's industrial region, gained notoriety due to the fossiliferous occurrences of Guabirotuba Fauna, one of the few fossil occurrences representing the Paleogene in the country and that defines a relative age for the fill of the basin. The facies analysis of the outcrop aimed to refine the knowledge about the unit's sedimentary deposits and thus to contribute to future taphonomic and paleoenvironmental studies. For this purpose, methods of faciological analysis were used in three representative segments of the outcrop, in which sedimentary facies, architectural elements, eodiagenetic features (calcrete), and bedrocks. The compositional characterization of the sediments was complemented with petrographic analyses. The depositional context of the Guabirotuba Formation was interpreted as shallow channel deposits and floodplains of braided rivers in distributary fluvial systems. The facies of sands and gravels, in bars that fill channel features, were interpreted as proximal portions, where deposits of channels amalgamated by frequent avulsion. These deposits are interspersed with associations of mud, sheets, and sandy lenses, characterized as lateral spreading deposits in distal portions of the system. In the cuts that make up the outcrop, important fossiliferous discoveries have been made in recent years. This was one of the reasons that made the conservation area, protected by municipal decree. Considering such novelties, and the fact that the original Guabirotuba Formation section was hidden by urbanization, it is proposed to designate the outcrop as a type area and the set of sections as a new type-section of the unit.
\end{abstract}

Keywords: Curitiba Basin; Continental Rift of Southeastern Brazil; Paleogene. 


\section{INTRODUÇÃO}

A Bacia de Curitiba localiza-se na porção leste do Estado do Paraná, constituindo o substrato da cidade homônima e sua região metropolitana. Geologicamente, a bacia integra o segmento ocidental do Rift Continental do Sudeste do Brasil, desenvolvido no Cenozoico (Figura 1).

Os estudos que caracterizaram a origem e evolução da bacia, bem como da Formação Guabirotuba (Bigarella e Salamuni, 1962; Becker, 1982; Salamuni et al., 1999), tiveram caráter regional, com descrição de muitos afloramentos que não existem mais, devido ao avanço da urbanização. Esses estudos também são anteriores à descoberta de fósseis e à definição da Fauna Guabirotuba (Sedor et al., 2017b), que contribuíram para estabelecer idade mais precisa para o preenchimento da bacia, além de constituírem uma das raras ocorrências fossilíferas conhecidas do Paleógeno no Brasil.

Este artigo apresenta modelos deposicionais e considerações paleoambientais, com base em análise de associações de fácies do Geossítio Bacia Sedimentar de Curitiba, afloramento fossilífero protegido, localizado no bairro Cidade Industrial de Curitiba. Apresenta também proposta de designação de nova seção-tipo para a Formação Guabirotuba no local, uma vez que descrições mais antigas, que poderiam ser informalmente consideradas estratotipos, foram ocultadas ou destruídas pela urbanização. O geossítio é protegido como unidade de conservação pelo município, pois, além de ser representativo da Formação Guabirotuba, abriga a única ocorrência de fósseis conhecida, de grande valor científico por sua raridade e diversidade.

\section{BACIA DE CURITIBA}

\section{A origem}

Desde o início do século passado se conhece a "pequena bacia sedimentar" localizada no Primeiro Planalto Paranaense (Carvalho, 1934; Oliveira e Leonardos, 1943), substrato ao crescimento da capital paranaense. Assim foi descrita por Bigarella e Salamuni (1962), que mencionam que o marco zero da cidade assenta-se em sedimentos dessa bacia. A expansão inicial da cidade priorizou esses depósitos, evitando, assim, os terrenos de rochas metamórficas. A Bacia de Curitiba tem seus depósitos aflorantes ou em subsuperfície no município homônimo e parte da sua região metropolitana, compreendendo área de aproximadamente $1.150 \mathrm{~km}^{2}$ (Riccomini et al., 2004).

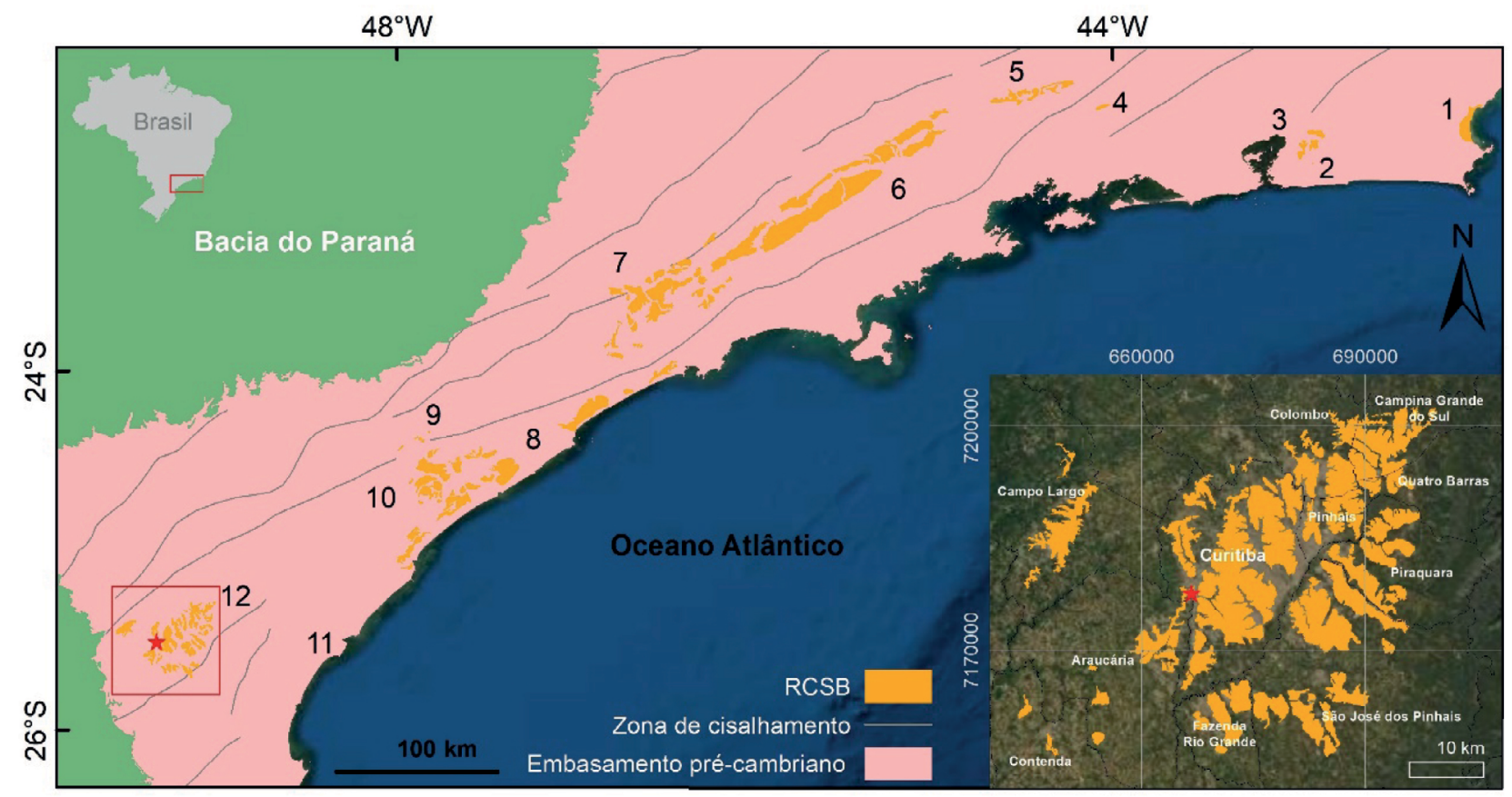

Fonte: modificado de Riccomini et al. (2004), CPRM (2004), Salamuni et al. (1999), IBGE (2015) e ESRI (2020).

Figura 1. Localização da Bacia de Curitiba no contexto regional do Rift Continental do Sudeste do Brasil - RCSB [Bacias: de Itaboraí (2), do Macacu (3), Volta Redonda (4), de Resende (5), de Taubaté (6), de São Paulo (7), de Curitiba (12). Grábens: de Barra de São João (1), de Seta Barras (9), de Guaraqueçaba (11), de Cananeia (8). Formações: Pariquera-Açu (10), Alexandra (11)]. Estrela vermelha indica o Geossítio Bacia Sedimentar de Curitiba, coordenadas UTM S22: 666700, 7177700 WGS84. 
Almeida (1976) incluiu a Bacia de Curitiba no Sistema de Rifts da Serra do Mar, região do Sudeste brasileiro formada por vales, montanhas e bacias de origem tectônica, desenvolvido no final do Mesozoico, com estruturação influenciada pelo embasamento (Cinturão Ribeira) de direções ENE e NE. Em 1989, Riccomini propôs a estrutura tectônica Rift Continental do Sudeste do Brasil (RCSB), definido como uma feição alongada e deprimida paralela e distando $70 \mathrm{~km}$ da linha de costa, entre os Estados do Paraná e do Rio de Janeiro. Nessa concepção, a Bacia de Curitiba localiza-se no segmento ocidental do RCSB, adjacente aos grábens de Guaraqueçaba, Sete Barras, Cananeia, assim como as áreas de exposição das formações Alexandra e Pariquera-Açu. O rift teve sua origem e seu desenvolvimento associados a reativações de estruturas regionais do embasamento, relacionadas com ruptura continental e formação do Oceano Attântico Sul (Riccomini et al., 2004). Zalán e Oliveira (2005) definiram a mesma estrutura regional como Sistema de Riftes Cenozoicos do Sudeste do Brasil, constituído por grábens alongados, assimétricos e com assoalho mergulhando para NW, nucleados a partir de antigas estruturas dúcteis subverticais do Ciclo Brasiliano. Mesmo com evidências de controle estrutural nas bordas, os autores consideram que, na escala utilizada para o estudo, a Bacia de Curitiba não integraria o sistema de riftes, sendo apenas uma "depressão topográfica” entre os grábens Ribeira e Marítimo.

Ao estudar a estruturação da Bacia de Curitiba, Salamuni et al. (2003) relacionaram sua formação com a tectônica extensional formadora do RCSB, com o registro de falhas normais e o desenvolvimento de um gráben, formando, assim, uma depressão alongada segundo NE-SW, que propiciou a deposição e preservação da Formação Guabirotuba. Segundo os autores, há evidências de atividades tectônicas posteriores à deposição dos sedimentos que estariam relacionadas a evento de compressão com registros transtrativos nos sedimentos e transpressivos no embasamento.

O embasamento da bacia foi descrito como formado por rochas metamórficas pré-cambrianas (Bigarella e Salamuni, 1962). Tais rochas compreendem uma faixa alongada de direção NE-SW integrante do Complexo Atuba, composta principalmente por gnaisses bandados, migmatizados, com intercalações de anfibolitos e xistos, em fácies anfibolito. É limitada ao noroeste pelas sequências metassedimentares do Grupo Açungui e ao leste por granitoides da Província Graciosa (Siga Jr. et al., 1995).

\section{O preenchimento da bacia: Formação Guabirotuba}

Em registro pioneiro, Siemiradzki (1898) notificou a existência de camadas sedimentares assentadas sobre rochas cristalinas nos arredores da cidade de Curitiba. Os sedimentos foram descritos inicialmente como cascalhos, argilas esverdeadas-avermelhadas para o topo do depósito, com intercalações de leitos grossos e finos e espessura que não excederia 40 m (Carvalho, 1934; Maack, 1947). Ao definir a Formação Guabirotuba, assim nomeada por a melhor exposição dos sedimentos ocorrer no bairro homônimo, Bigarella e Salamuni (1962) apresentaram-na como constituída por argilitos de tons cinza que apresentam cor avermelhada quando intemperizados, com lentes de arcóseo, depósitos rudáceos nas margens da bacia e horizontes de impregnação calcária (caliche), com espessura total não ultrapassando $60 \mathrm{~m}$.

Coutinho (1955) relatou a ocorrência de pequenos cristais de mineral róseo, identificado como lantanita, um carbonato de elementos terras-raras, geneticamente associado às camadas calcíferas. Posteriormente, Coimbra e Riccomini (1985) comparam tais ocorrências de caliches da Bacia de Curitiba com as bacias de Taubaté e de Resende, também integrantes do RCSB, e sugeriram que esses horizontes de calcário com formação de lantanita em areias e lamas verdes indicariam sincronicidade entre as bacias.

Bigarella e Salamuni (1962) propuseram que a sedimentação ocorrera em clima semiárido, na forma de leques aluvionares que coalesciam rumo ao centro da bacia em um ambiente playa-lacustre, o que explicaria a existência dos depósitos rudáceos na periferia e as camadas lenticulares de arcóseos intercaladas aos depósitos de lama na área central. Essa interpretação assemelha-se a outras propostas anteriores (Carvalho, 1934; Maack, 1947; Bigarella e Salamuni, 1959; Bigarella et al., 1961) e posteriores (Becker, 1982; Salamuni et al., 1999), que consideraram tais depósitos como, mais genericamente, fluviais e lacustres. Lima et al. (2013) definiram seis associações de fácies para as lamas, as areias imaturas e os cascalhos da unidade, atribuindo-as a depósitos de sistemas fluviais distributários, em clima úmido com alternância de períodos secos, que contribuíram para a formação dos calcretes, considerados por Cunha (2011) como de origem predominantemente freática.

Até há alguns anos, a idade da sedimentação na bacia não era bem definida, uma vez que a unidade era considerada afossilífera. Diversas propostas de idade foram sugeridas, com base em: relações geomorfológicas (pediplanos e pedimentos); comparação com outras bacias do RCSB; e dados palinológicos: Holoceno (Carvalho, 1934); Pleistoceno (Maack, 1947; Bigarella e Salamuni, 1958; Azevedo, 1981); Plio-Pleistoceno (Bigarella et al., 1961; Bigarella e Salamuni, 1962); Plioceno (Oliveira, 1927; Becker, 1982; Garcia et al., 2013); Mio-Plioceno (Salamuni et al., 2003); e Oligo-Mioceno (Salamuni et al., 2004).

Com a descoberta, por Liccardo e Weinschütz (2010), dos primeiros fósseis na Formação Guabirotuba, estudos que se seguiram identificaram uma nova fauna paleógena, denominada Guabirotuba, constituída de mamíferos, aves e répteis, entre outros (Sedor et al., 2014). A idade relativa 
da deposição da unidade foi estabelecida como do período Paleógeno, mediante correlação da Fauna Guabirotuba com a unidade biocronológica Barrancano da SALMAs - South American land mammal ages, a qual corresponde a um intervalo do Eoceno médio que abrange as idades Lutertiano e Bartoniano. Outras unidades do RCSB nas quais foram encontrados fósseis do mesmo período são as bacias de Itaboraí, com fósseis do Eoceno inferior; e de Taubaté, com fósseis do Oligoceno superior ao Mioceno inferior (Sedor et al., 2017b).

Outras unidades, desmembradas da Formação Guabirotuba, foram propostas para o preenchimento da Bacia de Curitiba, todavia não há consenso sobre sua aceitação: a Formação Tinguis, constituída por depósitos de retrabalhamento da Formação Guabirotuba, e a Formação Boqueirão, depositada por rios anastomosados, ambas propostas por Becker (1982), além da Formação Piraquara, de Coimbra et al. (1996), representada por depósitos de sistemas fluviais meandrantes.

\section{O geossítio Bacia Sedimentar de Curitiba}

O local de estudo situa-se no km 597 da BR 376, Cidade Industrial de Curitiba, em área de 16 ha denominada Geossítio Bacia Sedimentar de Curitiba (Fernandes et al., 2016; Sedor et al., 2017a). Essa designação para o afloramento foi proposta segundo conceitos de geoconservação do patrimônio geológico, por seu elevado valor científico.

Sua grande relevância paleontológica associa-se também à geológica, pois o geossítio constitui importante exposição representativa da Formação Guabirotuba, algo que a urbanização torna cada vez mais rara. Esses foram os principais motivos para que medidas de geoconservação fossem discutidas desde 2015 (Lima et al., 2015) com a Secretaria do Meio Ambiente de Curitiba e com integrantes do Grupo de Pesquisa em Geoconservação e Patrimônio Geológico (Conselho Nacional de Desenvolvimento Científico e Tecnológico/ Universidade Federal do Paraná [CNPq/UFPR]) e do Museu de Ciências Naturais da UFPR. Tal iniciativa culminou no estabelecimento de uma Área de Relevante Interesse Ecológico (ARIE) e na criação o Parque Paleontológico Formação Guabirotuba - Geossítio de Curitiba, um local para conservar e garantir a continuidade das pesquisas no local (Decreto Municipal no 286/2018).

Ao descrever o afloramento, Lima et al. (2013) caracterizaram-no como constituído pelas associações que denominaram de $\mathrm{D}$ e $\mathrm{E}$, respectivamente interpretadas como depósitos de rios rasos dominados por inundação laminar arenosa e de rios entrelaçados de baixa sinuosidade, rasos e cascalhosos, ambos em ambiente deposicional de leque aluvial, o primeiro distal proveniente da porção leste da bacia e o segundo proximal, originado na borda oeste.

Cunha (2011) caracterizou, para o mesmo local, a ocorrência de dois tipos de horizontes com cimentação carbonática, calcretes nodular e laminar, ambos nas porções arenosas. As microtexturas descritas pela autora, do tipo alfa de Wright (1990), foram atribuídas à precipitação predominantemente inorgânica, associadas a calcretes de origem freática.

Em estudo de caráter tafonômico, Cunha (2016) definiu duas fases de deposição e preservação dos fósseis, com passagem gradual. A primeira caracterizada por contexto de rios entrelaçados de alta energia e a segunda, por um sistema de planícies fluviais distais com rios efêmeros de baixa energia. A fauna Guabirotuba foi caracterizada como parautóctone, por apresentar características de curtas distâncias de transporte, com fósseis encontrados em todos os intervalos estratigráficos, sem alteração das características do habitat.

O estudo de proveniência de minerais pesados, realizado por Machado et al. (2012), constatou que os sedimentos da área estudada apresentam assembleia com provável área fonte as rochas do Complexo Atuba e do Grupo Açungui.

\section{MATERIAIS E MÉTODOS}

Para a caracterização da unidade, foram definidas três seções (Seção Guabirotuba 1, 2 e 3 - SG1, SG2 e SG3) dos cortes que compõem o afloramento, os quais foram descritos com o auxílio de seções horizontais (Figura 2) e perfis verticais (Figura 3), para identificação de fácies e suas associações. Foram também medidas atitudes de estruturas sedimentares, para análises de paleocorrentes, assim como registrada a ocorrência de modificações eodiagenéticas.

A Formação Guabirotuba tem sido caracterizada como composta ora por rochas sedimentares, ora por sedimentos. Essa divergência, muito provavelmente, se deve ao baixo grau diagenético atingido pelos depósitos, o que preservou suas características, sobretudo texturais, de sedimentos pouco consolidados. A sequência sedimentar que preencheu a Bacia de Curitiba praticamente não foi submetida a soterramento pós-deposicional. Os depósitos alcançaram, no máximo, o início da fase eodiagenética, na qual ocorreram início da compactação mecânica e alguma cimentação por carbonato (calcretes), fatos que justificam, também, a baixa coesão do material, que se apresenta, em geral, friável. Por tais motivos, optou-se por tratar os materiais componentes da formação como sedimentos: cascalhos, areias e lamas.

$\mathrm{Na}$ individualização de fácies sedimentares foram consideradas as características composicionais, texturais e estruturais dos sedimentos, segundo a definição de Walker (1992). As fácies foram definidas e identificadas por códigos propostos por Miall $(1977,2006)$, sendo a primeira letra em maiúsculo correspondente ao tamanho do grão predominante $(\mathrm{G}=$ cascalho, $\mathrm{S}=$ areia, $\mathrm{F}=$ lama $)$, seguida por uma letra minúscula indicativa de textura ou estrutura sedimentar principal encontrada na fácies. As acumulações diagenéticas, como a cimentação carbonática (calcretes), 
não foram consideradas na definição das fácies, por serem produtos de processos pós-deposicionais.

As associações de fácies foram agrupadas com base na relação espacial e nas variações laterais e verticais entre elas, com o auxílio da análise dos elementos arquitetônicos, necessariamente coetâneos e geneticamente associados no ambiente deposicional. Os elementos arquitetônicos foram reconhecidos com o auxílio dos fotomosaicos (Figura 2) e da descrição de campo, definidos e classificados mediante caracterização das fácies e formas internas e externas, segundo proposta de Miall $(1985,2006)$. A identificação de fácies e processos deposicionais permitiu estabelecer o contexto no sistema deposicional e sua discussão à luz dos modelos existentes.

\section{RESULTADOS}

\section{Análise litofaciológica}

Após descrição detalhada das três seções geológicas, foram definidas oito fácies sedimentares, apresentadas na Tabela 1 com suas características gerais.
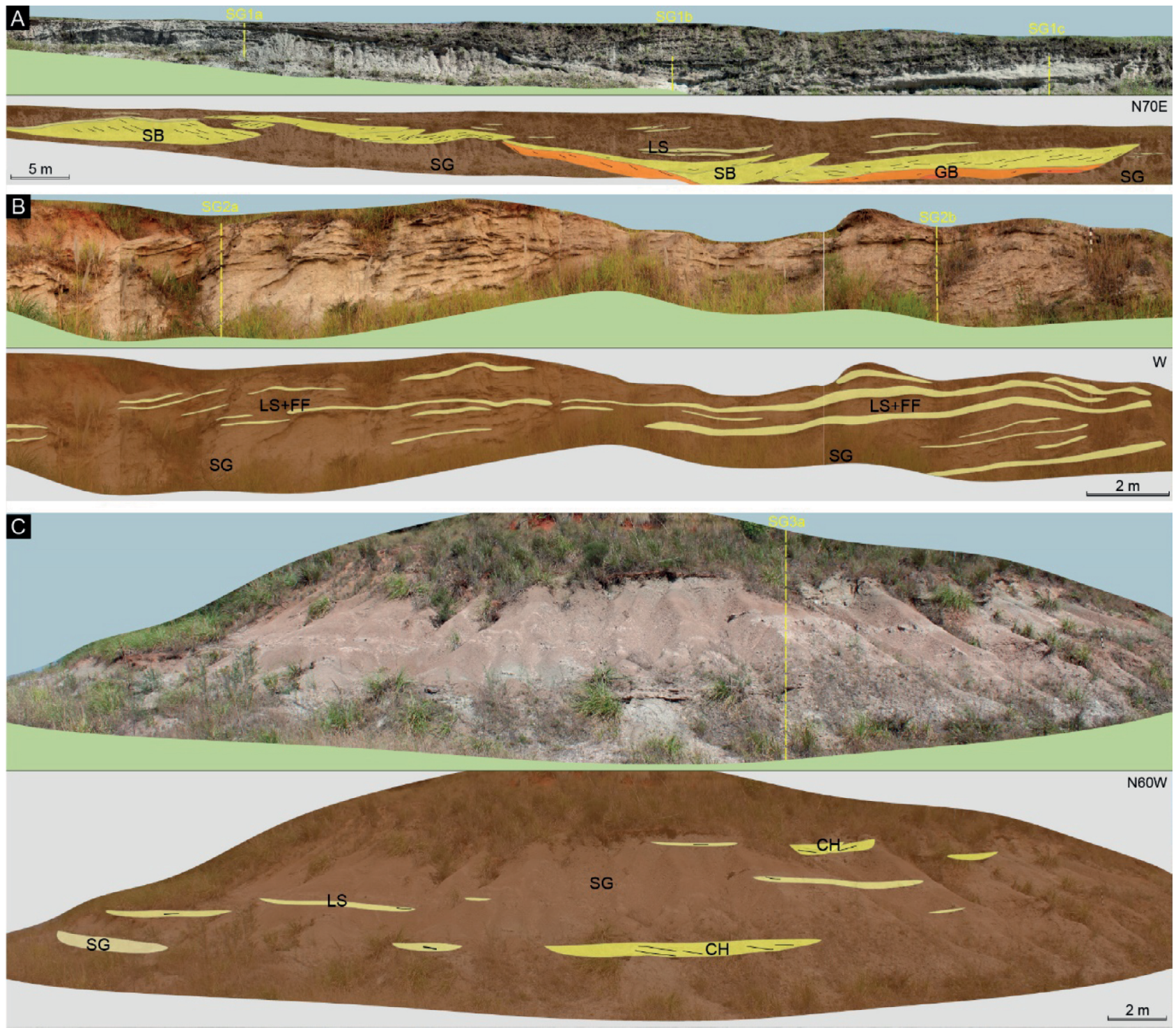

Figura 2. Visão geral e esquemática das seções: (A) Guabirotuba 1 - SG1, (B) Guabirotuba 2 - SG2 (B) e (C) Guabirotuba 3 - SG3. Linha tracejada amarela indica a localização das seções colunares. Elementos arquitetônicos: CH: canal, GB: barra cascalhosa, SB: barra arenosa, SG: sedimentos de fluxo de gravidade, LS: lençol de areia, FF: sedimentos de transbordamento. Escala vertical = escala horizontal. 


\section{Cascalhos}

Os cascalhos, que formam os depósitos de menor volume no afloramento, são constituídos predominantemente de seixos e grânulos polimíticos, com blocos em quantidade subordinada, e matriz de lama a areia grossa de composição quartzo feldspática. O arcabouço é mal selecionado, de baixa esfericidade e subarredondado, constituído por clastos de quartzo (de translúcido a leitoso esbranquiçado, acastanhado, preto), fragmentos de granitoide deformado, filito, quartzito, xisto, além de calcrete retrabalhado e ossos (bioclastos).

\section{Gh: cascalho sustentado por arcabouço}

Fácies constituída de depósitos rudáceos sustentados pelo arcabouço de grânulos a blocos com matriz de lama arenosa (Figura 4A). O arcabouço é muito mal selecionado, subanguloso a arredondado, de baixa esfericidade, com predomínio de clastos alongados a discoides, que definem
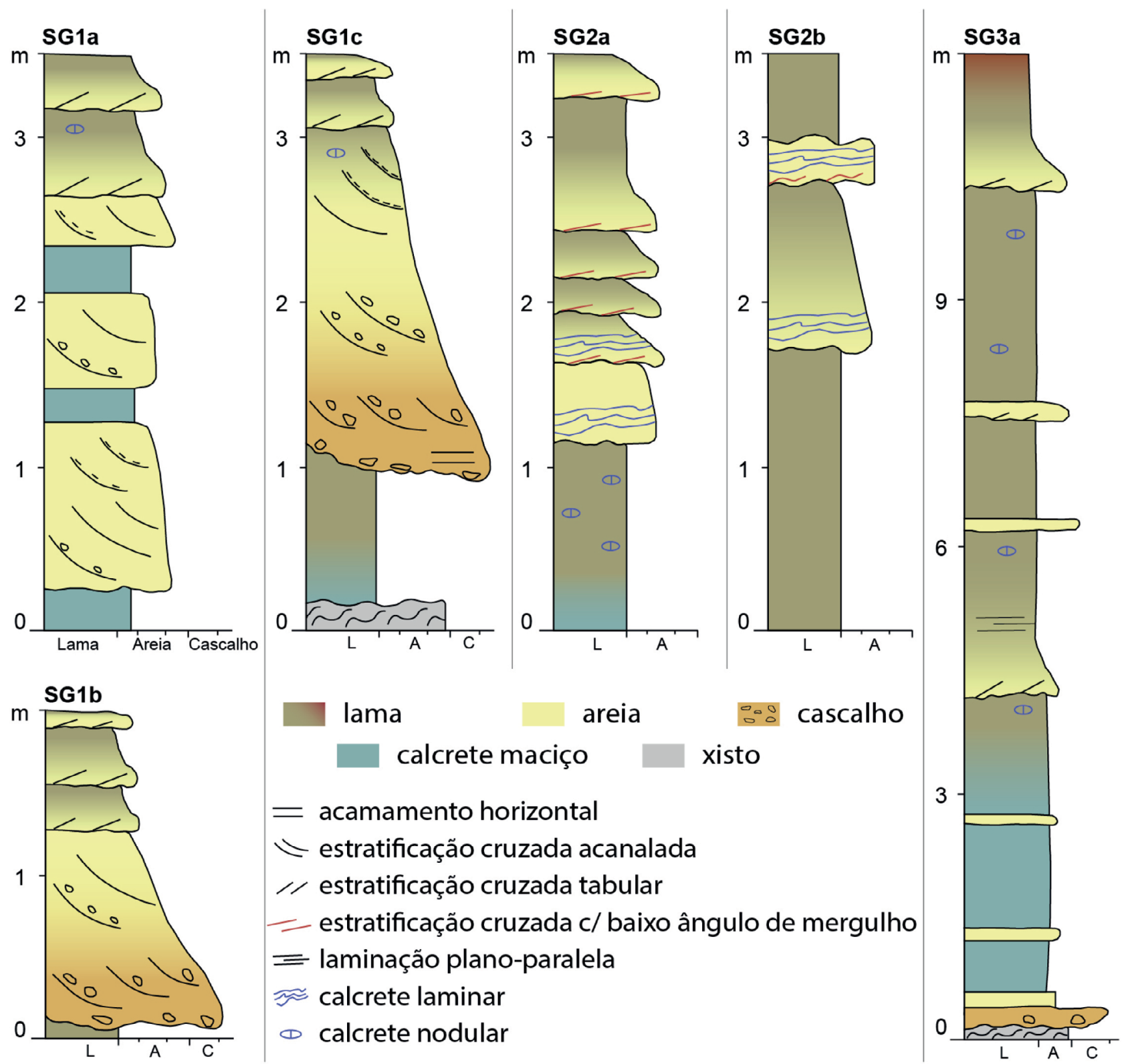

Figura 3. Perfis das seções Guabirotuba 1 (SG1a, SG1b e SG1c), Guabirotuba 2 (SG2a e SG2b) e Guabirotuba 3 (SG3a). A localização dos perfis, linha tracejada amarela, encontra-se na figura 2. 
um acamamento mal definido. Ocorre em estratos de forma lenticular com contato inferior erosivo, variando lateral e verticalmente para a fácies $\mathrm{Gm}$, com contato superior abrupto não erosivo com as fácies arenosas.

\section{Gm: cascalho sustentado por matriz}

Fácies composta de grânulos a seixos, com poucos blocos, sustentada por matriz de areia lamosa (Figura 4B). $\mathrm{O}$ arcabouço, mal selecionado, exibe estratificação cruzada acanalada mal definida formada pelo alinhamento de grãos alongados e discreta gradação normal para o topo. Ocorre em

Tabela 1. Fácies sedimentares definidas para o Geossítio Bacia Sedimentar de Curitiba.

\begin{tabular}{|c|c|c|}
\hline Código & Composição & Estrutura \\
\hline Gh & $\begin{array}{l}\text { Cascalho sustentado } \\
\text { por arcabouço }\end{array}$ & $\begin{array}{c}\text { Acamamento } \\
\text { horizontal mal definido }\end{array}$ \\
\hline$G m$ & $\begin{array}{c}\text { Cascalho sustentado } \\
\text { por matriz }\end{array}$ & $\begin{array}{c}\text { Estratificação cruzada } \\
\text { acanalada mal } \\
\text { definida e gradação }\end{array}$ \\
\hline St & $\begin{array}{c}\text { Areia fina a grossa, } \\
\text { pode conter cascalho }\end{array}$ & $\begin{array}{c}\text { Estratificação } \\
\text { cruzada acanalada }\end{array}$ \\
\hline Sp & $\begin{array}{c}\text { Areia fina a grossa, } \\
\text { pode conter cascalho }\end{array}$ & $\begin{array}{l}\text { Estratificação } \\
\text { cruzada tabular }\end{array}$ \\
\hline SI & Areia fina a grossa & $\begin{array}{c}\text { Estratificação cruzada } \\
\text { com baixo ângulo de } \\
\text { mergulho }\left(<15^{\circ}\right)\end{array}$ \\
\hline Sm & Areia fina a grossa & $\begin{array}{c}\text { Maciça a } \\
\text { estratificação incipiente }\end{array}$ \\
\hline Fl & $\begin{array}{l}\text { Lama, pode conter } \\
\text { areia muito fina }\end{array}$ & $\begin{array}{l}\text { Laminação } \\
\text { plano-paralela }\end{array}$ \\
\hline$F m$ & $\begin{array}{l}\text { Lama, pode conter } \\
\text { areia e cascalho }\end{array}$ & Maciça \\
\hline
\end{tabular}

camadas tabulares com base côncava. Passam lateralmente para a fácies Gh e verticalmente com contato gradual para fácies arenosa.

Areia

As fácies arenosas são constituídas predominantemente por grãos de quartzo e feldspatos de granulação muito fina a areia muito grossa, com matriz de lama esverdeada e/ou cimentação carbonática. Por vezes, contém grânulos e seixos - em menor quantidade blocos, de fragmento lítico, argila, calcrete retrabalhado e bioclasto (fósseis).

\section{St: areia com estratificação cruzada acanalada}

Fácies composta de areias de granulação muito fina a muito grossa, predominantemente média a grossa, com matriz de lama, por vezes, carbonática. Em algumas porções, contém até 15\% de grânulos e seixos. O arcabouço é constituído de quartzo e feldspato, moderadamente selecionado, em que predominam grãos subarredondados e de alta esfericidade. A estratificação cruzada acanalada é realçada pelo alinhamento dos clastos de cascalhos na base dos estratos (Figura 5A), ou pela intercalação concordante de lâminas de até $1 \mathrm{~cm}$ de lamas maciças (Figura 5B). Ocorre em camadas lenticulares ou tabulares de sets com até $1 \mathrm{~m}$ de espessura, com contato inferior gradual com a fácies $\mathrm{Gm}$ ou abrupto com a Gh, e superior transicional com a fácies Fm.

\section{Sp: areia com estratificação cruzada tabular}

Fácies de granulação areia fina a média, com areia grossa e seixos em quantidade subordinada, exibindo estratificação cruzada tabular, por vezes, realçada pela cimentação carbonática. Em algumas camadas, a estratificação exibe ondulações

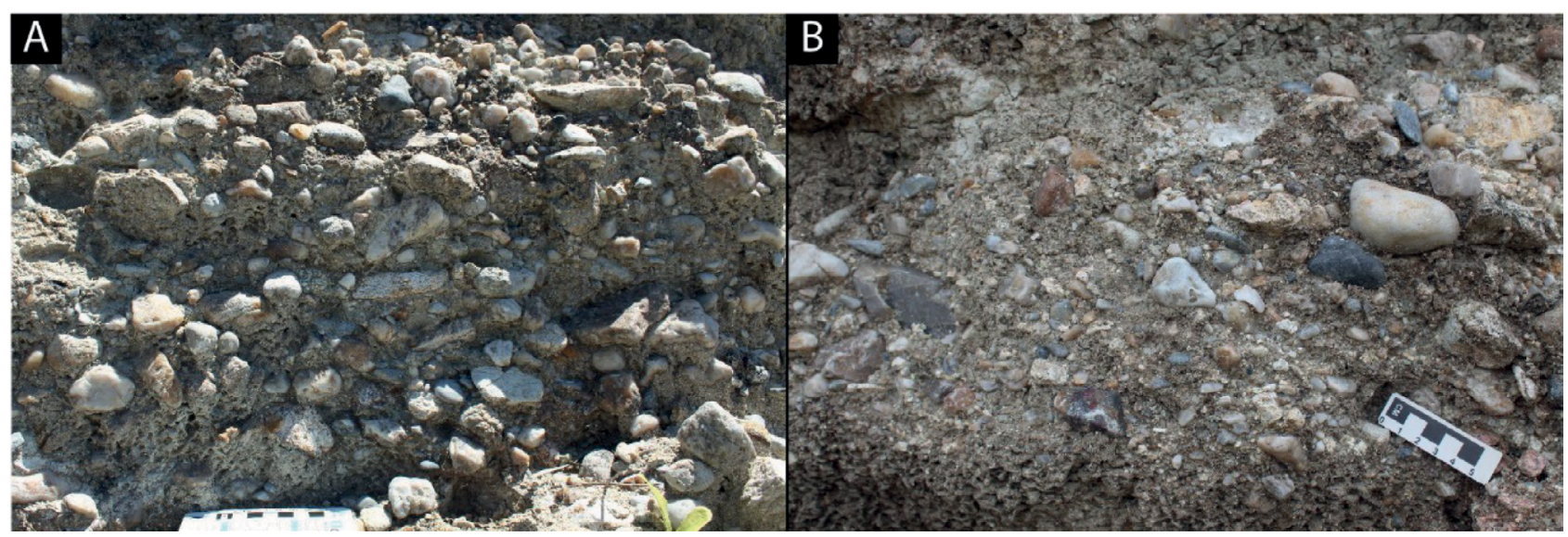

Figura 4. Cascalhos. (A) fácies Gh, cascalhos sustentados por arcabouço, com matriz de lama arenosa. Notar clastos mais alongados fracamente orientados; (B) fácies $\mathrm{Gm}$ com grânulos, seixos e blocos sustentados por matriz de areia lamosa, com estratificação cruzada acanalada. 
suaves (Figura 5C). O arcabouço é composto de grãos de quartzo e feldspato, moderadamente selecionados e predominantemente subarredondados e esféricos. Forma camadas lenticulares com base plana a côncava erosiva, com sets de aproximadamente $20 \mathrm{~cm}$ de espessura (Figura 5D). $O$ contato superior é gradual, com fácies lamosas $(\mathrm{Fm}, \mathrm{Fl})$.
SI: areia com estratificação cruzada com baixo ângulo de mergulho

Nesta fácies predomina areia fina a média, de seleção moderada e grãos subangulosos. Exibe estratificação cruzada incipiente, com mergulhos $<15^{\circ}$, que é ressaltada pelo

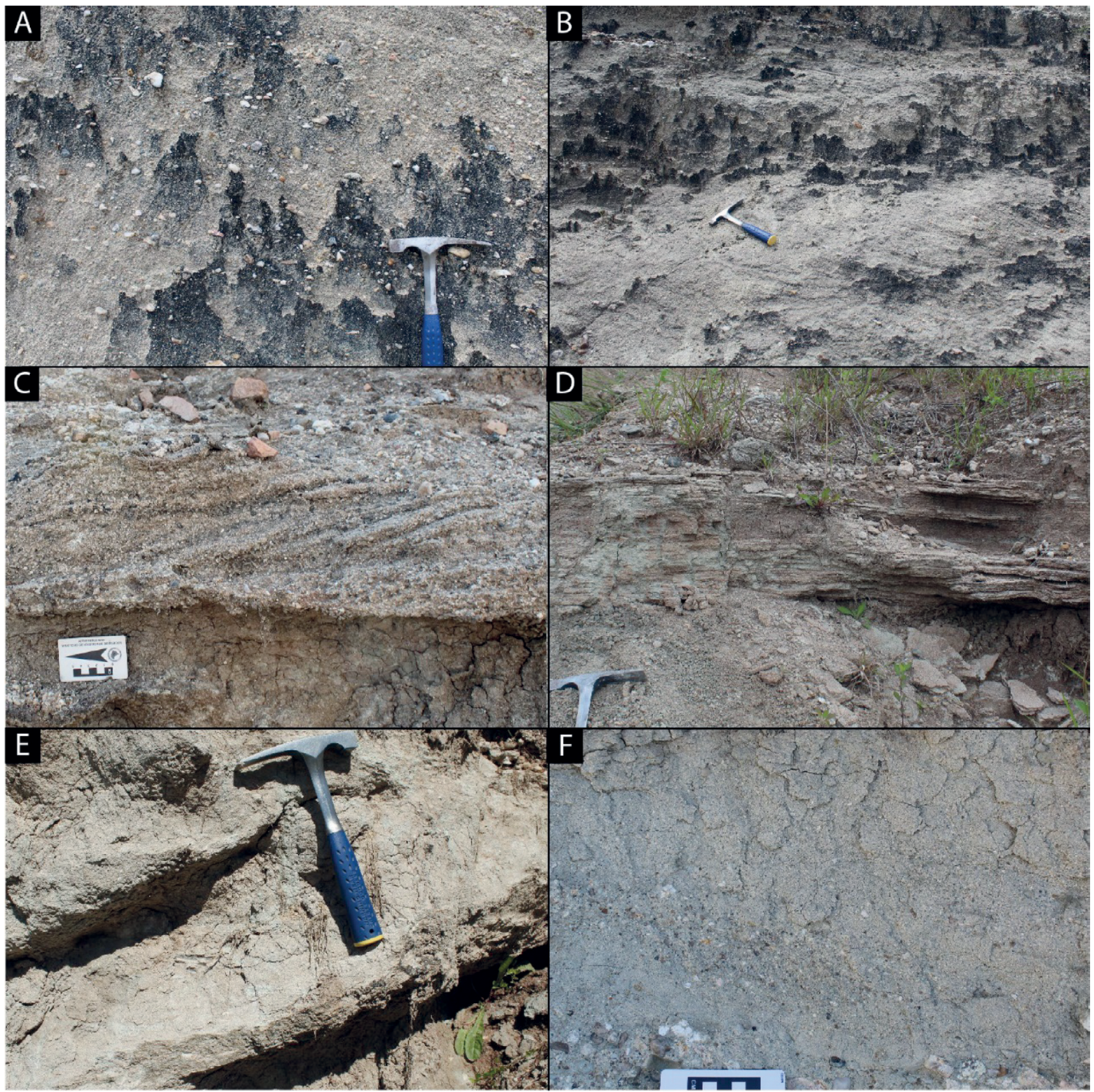

Figura 5. Fácies arenosas. (A) fácies St com estratificação realçada pela orientação dos clastos de cascalhos; (B) fácies St com estratificação realçada pela intercalação de lâminas de granulação areia fina/lama e areia média/grossa; (C) fácies Sp com estratificação cruzada tabular exibindo planos com ondulações suaves; (D) estrato de Sp em contato erosivo com fácies $\mathrm{Fm}$; $(\mathrm{E})$ fácies SI realçada por cimentação carbonática com passagem gradual para $\mathrm{Fm}$; $(\mathrm{F})$ areia maciça sobre fácies Gh com concentração de formato alongado de grânulos e seixos fracamente orientados. 
desenvolvimento de calcrete laminar paralelo às estruturas. Ocorre em camadas tabulares com base plana erosiva, com espessura média de $20 \mathrm{~cm}$ e variação vertical gradual para fácies Fm (Figura 5E).

\section{Sm: areia maciça a fracamente estratificada}

Fácies constituída de areia fina a grossa, moderadamente selecionada, que subordinadamente contém grânulos, seixos e fragmentos de argila dispersos ou concentrados em intercalações lenticulares (Figura 5F). Apresenta estrutura maciça predominante, por vezes, com estratificação cruzada incipiente. Ocorre em camadas lenticulares a tabulares com contato inferior abrupto ou não conformidade, sobre o embasamento.

A imaturidade das fácies Sm e St, característica observada macroscopicamente pela presença de matriz lamosa, má seleção e grãos de composição instável, foi verificada em seções delgadas. Em termos texturais, verificaram-se: matriz argilosa envolvendo grãos (caracterizada como esmectita, Figuras 6A e 6B) e baixo grau de seleção e arredondamento de parte do arcabouço. Em relação à imaturidade composicional (mineralógica), foram encontrados, principalmente na fração mais grossa do arcabouço, grãos de minerais física e/ou quimicamente mais instáveis ao intemperismo (Figuras 6C e 6D), como, por exemplo: feldspato, minerais máficos, clastos de argila e fragmentos líticos (granitoide). Também é frequente, nos grãos mais grossos, ocorrência de quartzo policristalino com contatos internos poligonais a interdigitados (quartzito).

\section{Lama}

As fácies de lama, que constituem depósitos que aumentam sua espessura para o topo do afloramento, apresentam

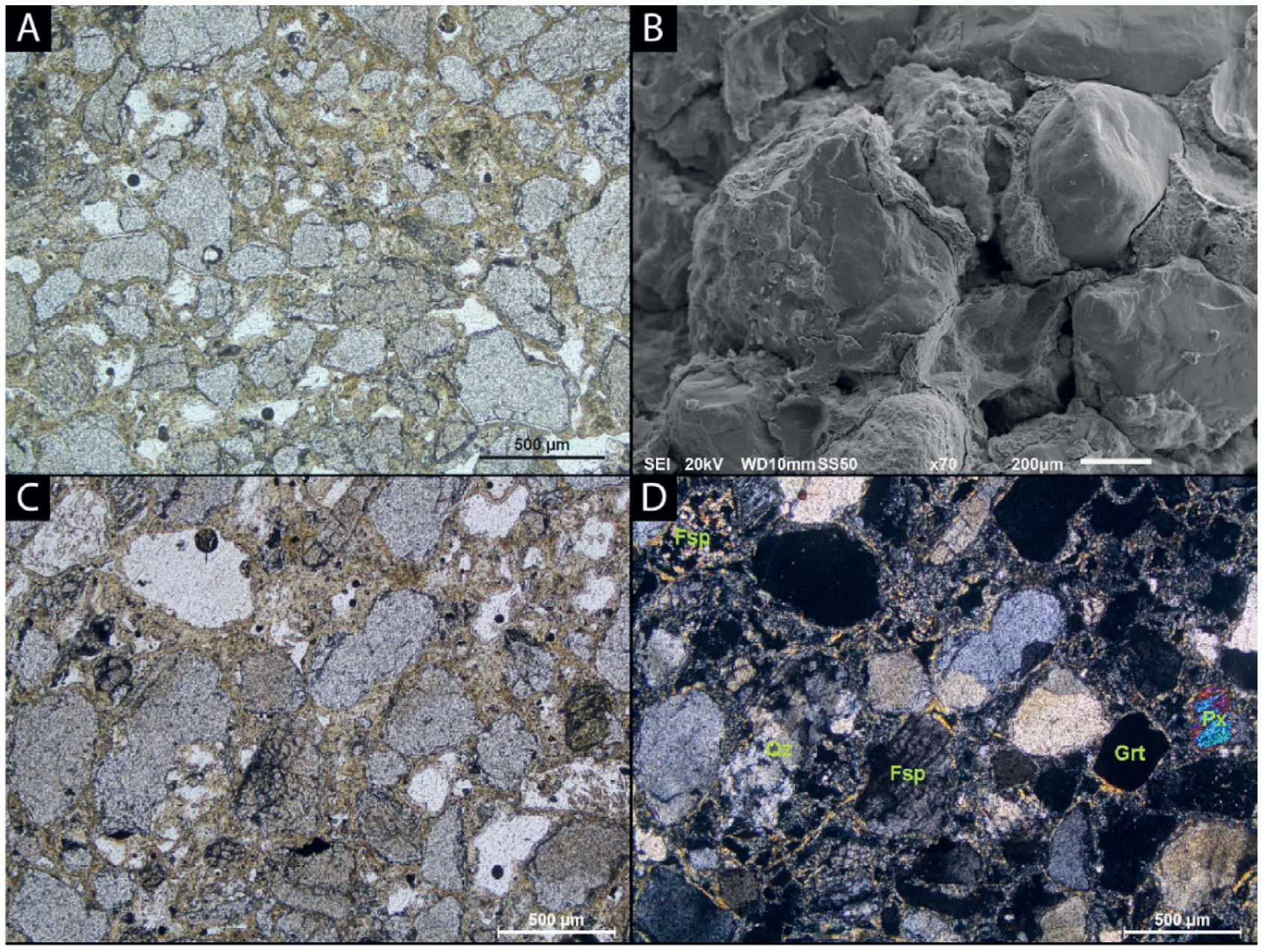

Figura 6. Imaturidade textural e composicional das areias. (A) aspecto geral exibindo matriz de cor acastanhada envolvendo os grãos; (B) detalhe da matriz de esmectita, no caso envolvendo e preenchendo espaços entre grãos de quartzo; (C/D) exemplo da composição mineral imatura do arcabouço: feldspato (Fsp), granada (Grt), piroxênio (Px) e quartzito (Qz). 
predomínio da fração argila e exibem cor esverdeada, passando de forma gradual para tons avermelhados, de alteração, na parte superior do corte (Figura 7).

\section{Fl: lama arenosa com laminação plano-paralela}

Fácies composta por lama com proporções variadas de areia muito fina a fina, com fraco a moderado desenvolvimento de laminação. Integra camadas lenticulares a tabulares, com sets de cerca de $10 \mathrm{~cm}$ de altura, sendo que para a base passa gradualmente para fácies $\mathrm{Sp}$ e ao topo, para fácies $\mathrm{Fm}$.

\section{Fm: lama maciça}

Fácies constituída predominantemente de argila, com silte e areia muito fina em menores quantidades. São encontrados, em algumas camadas, grânulos a blocos dispersos, além de intercalações lenticulares de areias e cascalhos, com contatos difusos. Forma camadas maciças tabulares de espessuras centimétricas a métricas. Ocorre também como lentes de até $1 \mathrm{~cm}$ de espessura, associada com fácies arenosas. O contato inferior geralmente é feito de modo gradual, com fácies arenosas.

\section{Calcretes}

Os calcretes são constituídos por material cimentado por carbonatos, de arcabouço muito mal selecionado (característica original dos depósitos), formado por lama, areia e cascalho. Exibem texturas laminar, nodular ou maciça.
Na porção inferior da seção SG2 ocorrem calcretes nodular (Figura 8A) e laminar nas camadas mais arenosas (Figura 8B). Na seção SG3 predomina calcrete do tipo maciço, formando um estrato de $3 \mathrm{~m}$ de espessura com contato inferior irregular, levemente ondulado (Figura 8C), no qual internamente são encontradas porções de areia média a grossa com grânulos, não cimentadas por carbonato e delimitadas por argilas castanhas em contato abrupto com a porção cimentada. Acima dessa camada são encontrados apenas calcretes nodulares. Na porção inferior da seção SG1 são encontradas feições dômicas de calcrete maciço, além de pequenos bolsões do mesmo material entre as fácies Fm e Gh ou no interior da fácies St, deformando as estratificações (Figura 8D).

Os calcretes do tipo maciço ocorrem em horizontes de espessura métrica, predominantemente em areias e cascalhos, e por vezes próximo do contato com o embasamento. São constituídos de até $80 \%$ de carbonato micrítico, no qual estão imersos grãos siliciclásticos de composição, textura e tamanho variados. Como sua constituição é, ao menos em parte, dolomítica (Figura 9A), esse tipo de calcrete pode ser nomeado de dolocrete. Eventualmente, o cimento carbonático é espático, formando franjas de cristais romboédricos contornando os grãos (Figura 9B).

\section{Associações de fácies nas seções}

Para as seções analisadas, os elementos arquitetônicos (Figura 2) e suas fácies constituintes foram individualizados em:

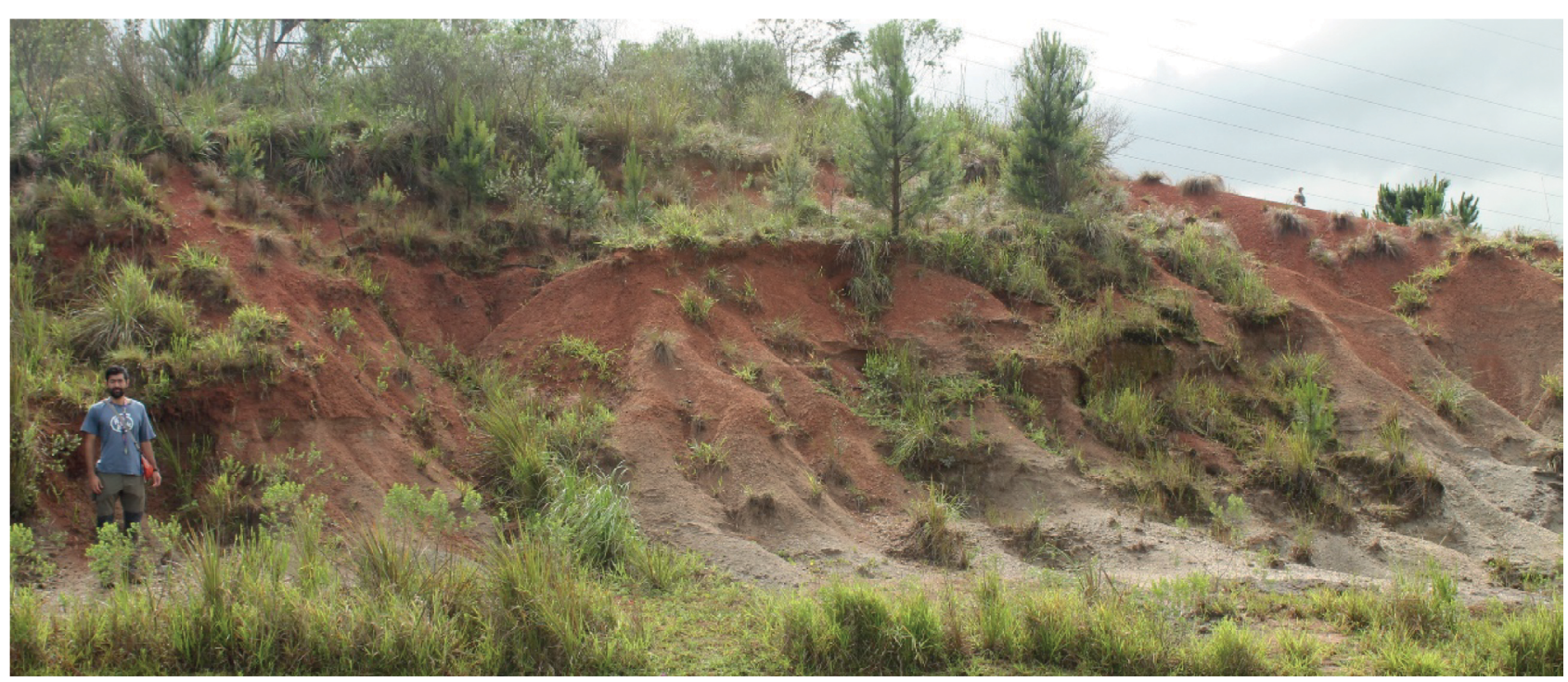

Figura 7. Exposição de fácies lamosa $F m$, predominante no topo da seção estudada. Passagem gradual da cor esverdeada (7/10BG light greenish gray) a avermelhada (2,5YR red) de alteração, no topo. Porção central do afloramento, visada para leste. 
- canal - $\mathrm{CH}$, qualquer combinação de fácies, forma de lente ou camada alongada de base erosiva com concavidade para cima de dimensões e formas variadas;

- barra cascalhosa - GB, fácies Gm e Gh, lenticular e comumente intercalada com SB;

- barra arenosa - SB, fácies St e Sp, lenticular ou em cunha, ocorrem como preenchimento de canal;

- $\quad$ sedimentos de fluxo de gravidade — SG, fácies Sm e Fm, forma lobada ou lençol (inclui camadas espessas de lama com clastos dispersos), tipicamente intercalado com GB;

- lençol de areia - LS, fácies Sl e menos comum Sp, forma de lençol;
- sedimentos de transbordamento - FF, fácies Fm e Fl, camada tabular delgada comumente intercalada a LS.

Foram definidas duas associações de fácies distintas: uma constituída de depósitos de preenchimento de canal de rio entrelaçado, composta dos elementos $\mathrm{CH}, \mathrm{GB}$ e SB, com direção geral das paleocorrentes obtida nas fácies $\mathrm{St}$ com tendência para sudeste (Figura 10A); e outra formada por depósitos de planície de inundação, caracterizada pelos elementos SG, LL, FF e CH, nos quais as direções de paleocorrentes nas fácies $\mathrm{Sp}$ e Sl apontam uma fraca tendência para norte-nordeste e sudoeste (Figura 10B). A distribuição

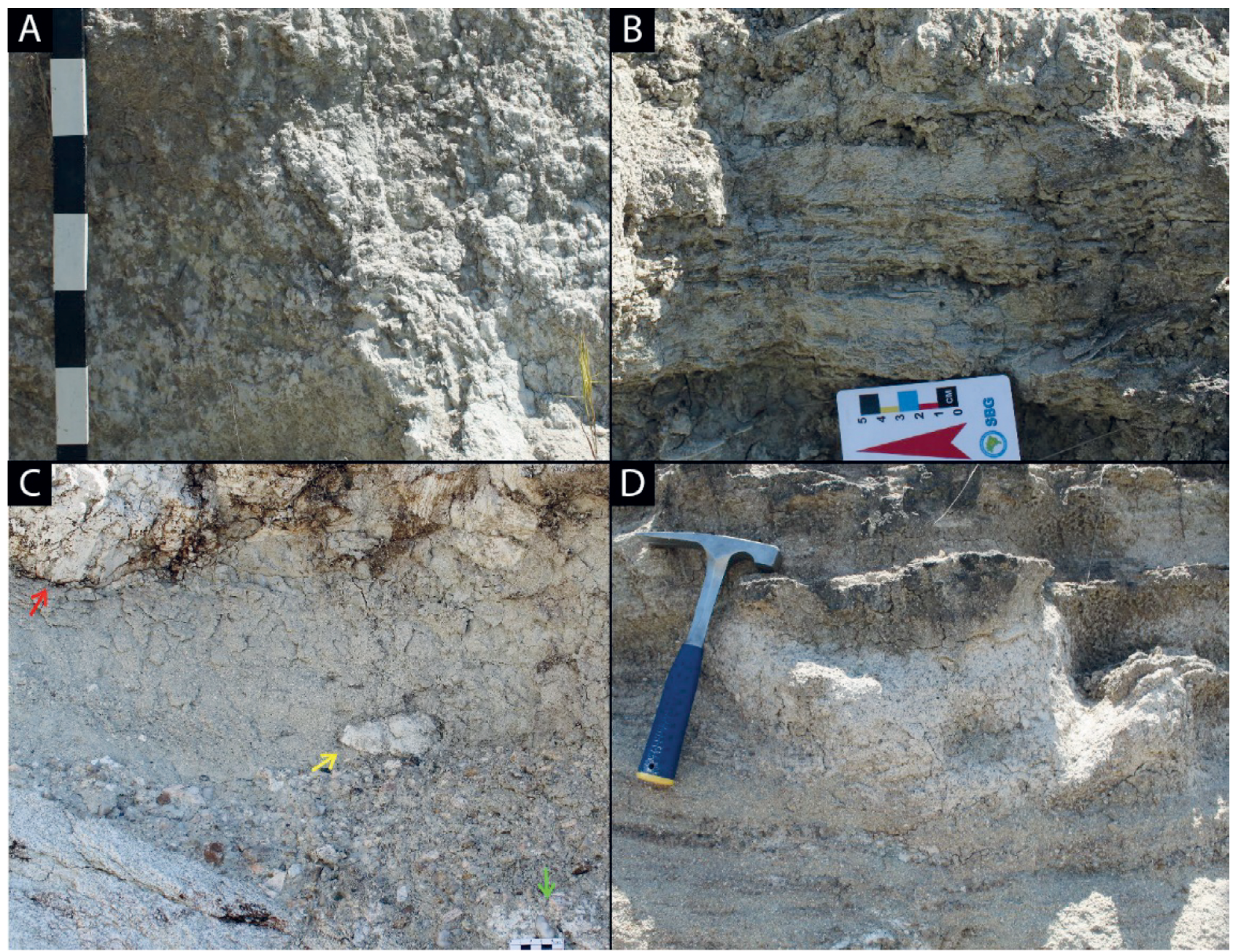

Figura 8. Texturas macroscópicas dos calcretes. (A) nodular, canto inferior esquerdo da seção SG2, na fácies Fm. Escala segmento de barra mede $10 \mathrm{~cm}$; (B) laminar, ressaltando a porção de granulação mais grossa da camada, fácies SI, seção SG2; (C) contato abrupto, ondulado, da camada de calcrete maciço com areia da fácies Sm (seta vermelha), nódulos de calcrete na fácies Sm (seta amarela) e Gh (seta verde), base da seção SG3; (D) bolsão de calcrete na fácies St, que deforma levemente as lentes de argilas (fácies Fm) que, por sua vez, evidenciam a estratificação, porção leste da seção SG1. 
dessas associações de fácies e características importantes das seções é apresentada a seguir.

\section{Seção Guabirotuba 1}

A SG1 é composta predominantemente da associação de preenchimento de canal, depósitos arenosos da fácies $\mathrm{St}$ e cascalhosos de Gm (SB e GB). Os cascalhos da fácies Gh marcam níveis de erosão sobre a associação de depósitos de planície de inundação composto de lamas maciças (SG), assim como ao topo ocorrem, intercaladas na fácies $\mathrm{Fm}(\mathrm{FF})$, camadas delgadas de passagem gradual da fácies Sp para $\mathrm{Fl} \mathrm{e} \mathrm{Fm} \mathrm{(CH/LS)} \mathrm{dessa} \mathrm{associação} \mathrm{de} \mathrm{fácies.}$

Sobre porções expostas do embasamento na parte inferior da seção, encontra-se um horizonte de calcrete maciço (perfil SG1c) que passa lateralmente para uma camada de lama maciça com calcrete nodular, vênulas de carbonato e rizocreções, concreções cilíndricas, por vezes, ramificadas de carbonato de tamanhos que variam de 5 a $30 \mathrm{~cm}$ de comprimento.

Foram identificadas fraturas com preenchimento de carbonato de cálcio. Esses planos eventualmente são contínuos ou paralelos a fraturas no embasamento, possível resultado de reativações neotectônicas de estruturas do embasamento após a sedimentação, não excluindo a possibilidade de deformações sindeposicionais e/ou penecontemporâneas quando apenas nos depósitos.

\section{Seção Guabirotuba 2}

Constituída essencialmente da associação de depósitos de planície de inundação, na qual na base há predominância da fácies lamosa $(\mathrm{SG})$, com ocorrência de calcrete maciço a nodular. Para o topo, ocorrem intercalações da fácies Sl e Fm (FF + LS), em que as porções arenosas são salientadas no afloramento pelo calcrete laminar, que, por vezes, oblitera as estruturas internas.

É principalmente nessa seção que são encontrados icnofósseis, em forma de galerias com ou sem preenchimento, os quais ocorrem principalmente nas fácies arenosas, geralmente associados a horizontes de calcrete laminar.

As camadas de areia, de contato inferior erosivo abrupto, por vezes, têm os limites inferior e superior ondulados, como a camada superior do perfil SG2b, a qual apresenta ondulação de perfil aparentemente simétrico, com comprimento de onda de $40 \mathrm{~cm}$, amplitude de $2 \mathrm{~cm}$ e eixo de crista de direção N350.

Além de delgadas vênulas de carbonato de cálcio na base da seção, foram encontrados planos de deposição de
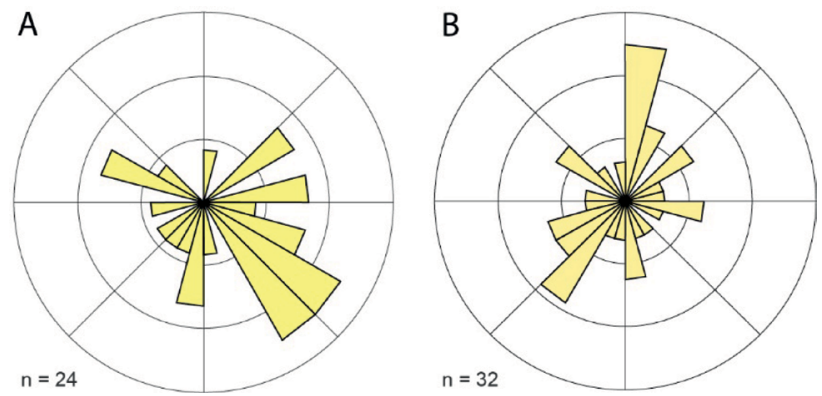

Figura 10. Diagramas de rumos de paleocorrentes medidas nas associações: (A) de preenchimento de canal, fácies St. $n=24$; (B) de planície de inundação, fácies Sp e Sl. $\mathrm{n}=32$. Intervalos de $15^{\circ}$ e contornos de $5^{\circ}$.

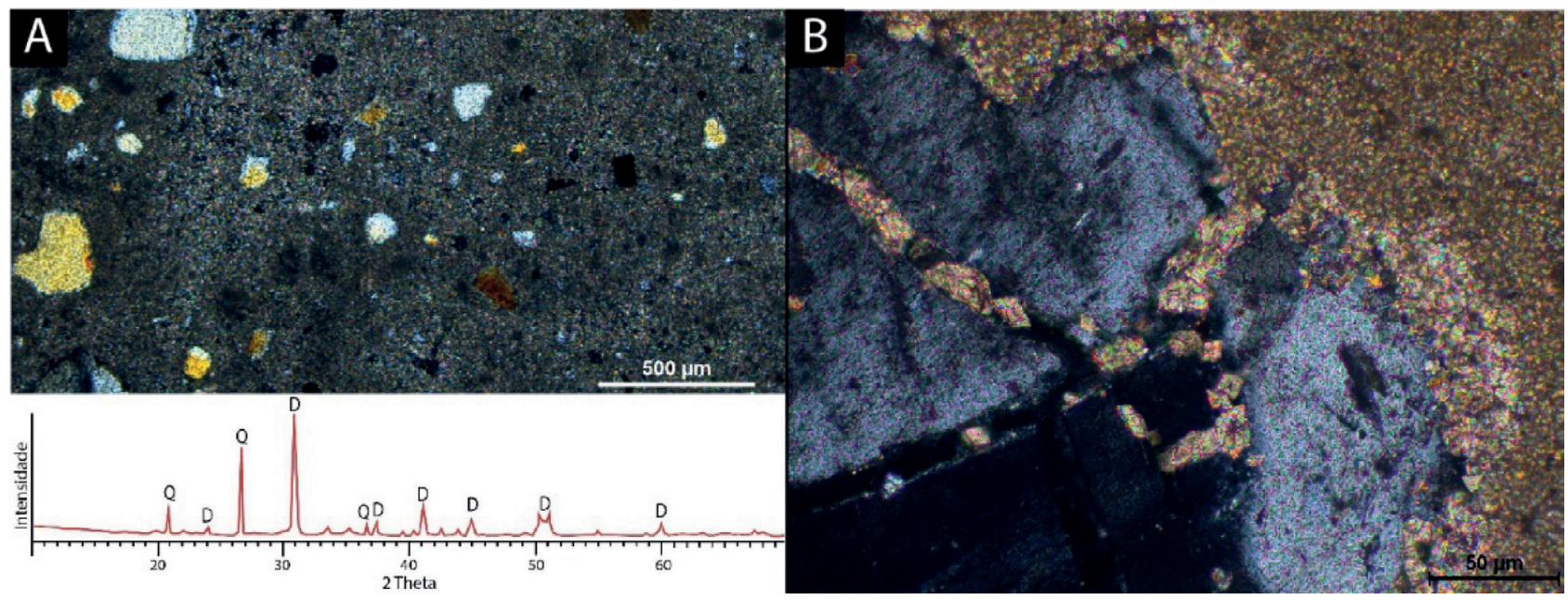

Figura 9. Calcrete maciço. (A) amostra com arcabouço de granulação predominantemente areia fina da seção SG1. Difratograma da amostra total exibindo picos dos grãos de quartzo (Q) e cimento de dolomita (D); (B) cristais romboédricos encontrados nas bordas dos grãos, por vezes, crescendo em fraturas, em amostra com arcabouço mal selecionado, variando de areia fina a grânulo, da seção SG3. 
carbonato remobilizado, que seccionam obliquamente as camadas de calcrete laminar e apresentam mergulhos de cerca de $50^{\circ}$, estes apresentam limites difusos, com espessura, em média, de $5 \mathrm{~cm}$.

\section{Seção Guabirotuba 3}

Constituída da associação de depósitos de planície de inundação, com predomínio da fácies Fm (SG) intercalado a delgadas camadas lenticulares das fácies $\mathrm{Sp}$ e $\mathrm{Fl}(\mathrm{CH} / \mathrm{LS})$. Na base da seção, em não conformidade com os sedimentos, afloram xistos com foliação principal de atitude 15/30. Sobre as depressões da superfície de erosão no embasamento, encontram-se lentes de cascalhos da fácies Gh e areias da fácies Sm (SG). Uma camada de calcrete maciço, sobre os sedimentos alojados na superfície de erosão, marca o começo das lamas para o topo da seção.

Próximos à transição das argilas esverdeadas para avermelhadas, que acontece na parte superior da seção, ocorrem cristais róseos de lantanita. Os cristais, de até $3 \mathrm{~cm}$, são encontrados na superfície do afloramento com hábito placoide, em roseta ou anédrico, por vezes, maciço incrustando porções de sedimentos.

\section{DISCUSSÃO}

\section{Contexto deposicional}

As duas associações de fácies, de preenchimento de canal e de planície de inundação, assemelham-se aos depósitos sedimentares de sistemas fluviais distributários descritos por Fisher et al. (2007), Nichols e Fisher (2007), ou distributivos de Weissmann et al. $(2010,2015)$, além de condizerem com a interpretação proposta por Lima et al. (2013) ao caracterizarem regionalmente a Formação Guabirotuba.

A porção intermediária do segmento SG1, associação de preenchimento de canal, muito se parece com as associações encontradas nas zonas proximais do sistema fluvial distributário descritas por Nichols e Fisher (2007). Os autores as caracterizam como depósitos de barras compostas por fácies arenosas (SB) ou cascalhosas (GB) com clastos imbricados e estratificações cruzadas, de rios entrelaçados. Eles também descrevem a preservação de depósitos de canais amalgamados, indicando alta mobilidade, migração lateral e ausência de depósitos de planície de inundação devido ao retrabalhamento pelas repetidas avulsões características do sistema.

Enquanto as associações de planície de inundação que constituem a SG2 e a SG3, camadas métricas de depósitos de lamas maciças ( $\mathrm{SG}$ ), intercaladas com pequenas lentes ou lençóis de areia (LS), são similares às características descritas por Fisher et al. (2007) para porções mais distais do sistema fluvial distributário. Ali predominam camadas espessas e contínuas de lamas maciças depositadas por fluxos subaéreos desconfinados, de baixa energia. Junto a essas lamas ocorrem delgados depósitos de preenchimento de canal, lentes e lençóis de areia formados principalmente por espraiamento lateral e terminal de canais, por vezes, interdigitados a depósitos de lagos rasos e efêmeros.

As camadas tabulares de areia (LS) do perfil SG2b apresentam limites superiores com ondulações simétricas, similares ao descrito por Fisher et al. (2007) para depósitos distais do sistema fluvial distributário da Bacia de Ebro, Espanha. Os autores interpretaram-nas como depósitos de fluxos desacelerantes, que desembocam em lago raso, com posterior retrabalhamento por ondas. As ondulações aqui descritas podem também ser atribuídas a acomodações atectônicas posteriores à deposição, de sobrecarga, decorrentes de pequenos movimentos gravitacionais, ou até de respostas a esforços tectônicos compressivos direção EW (Salamuni et al., 2003), que formariam estruturas de orientação NS, similares às dos eixos de cristas das ondulações.

A correlação das associações de fácies com o modelo deposicional de sistema fluvial distributário (Tabela 2) indica que nessa porção da bacia ocorreram intercalações de depósitos distais e proximais do sistema. Rumos de paleocorrentes medidos no local, mesmo com a grande dispersão característica de rios entrelaçados, sugerem essa intercalação devido à interação de sistemas deposicionais adjacentes. Não se descarta, portanto, a possibilidade de corresponderem a depósitos de rios provenientes da borda oposta da bacia, como proposto por Lima et al. (2013).

\section{Composição}

As fácies cascalhosas são compostas de uma variedade de litoclastos, além dos clastos de quartzo e feldspatos.

Tabela 2. Correlação entre associações de fácies e localização no sistema fluvial distributário.

\begin{tabular}{|c|c|c|c|c|}
\hline Seção & Fácies & $\begin{array}{c}\text { Elemento } \\
\text { arquitetônico }\end{array}$ & Associação & $\begin{array}{c}\text { Porção do } \\
\text { sistema }\end{array}$ \\
\hline \multirow[t]{2}{*}{ SG1 } & $\begin{array}{c}\text { Gh, } \\
\text { Gm, St, } \\
\text { Sp, Fm }\end{array}$ & $\mathrm{CH}, \mathrm{GB}, \mathrm{SB}$ & Canal & Proximal \\
\hline & $\mathrm{Fm}$ & LS/FF, SG & & \\
\hline SG2 & $\mathrm{SI}, \mathrm{Fm}$ & LS/FF, SG & Planície De & \\
\hline SG3 & $\begin{array}{c}\text { Sp, Fl, } \\
\text { Sm, } \\
\text { Fm }\end{array}$ & $\begin{array}{c}\mathrm{CH}, \mathrm{LS} / \mathrm{FF}, \\
\mathrm{SG}\end{array}$ & Inundação & Distal \\
\hline
\end{tabular}

Seções - SG1: Guabirotuba 1; SG2: Guabirotuba 2; SG3: Guabirotuba 3; Gh: cascalho sustentado por arcabouço; Gm: cascalho sustentado por matriz; St: areia com estratificação cruzada acanalada; Sp: areia com estratificação cruzada tabular; SI: areia com estratificação cruzada com baixo ângulo de mergulho; Sm: areia maciça; Fl: lama arenosa com laminação plano-paralela; Fm: lama maciça; CH: canal; GB: barra cascalhosa; SB: barra arenosa; SG: sedimentos de fluxo de gravidade; LS: lençol de areia; FF: sedimentos de transbordamento. 
Essa composição condiz com a natureza da área fonte da porção oeste da bacia, fornecedora de material proveniente da alteração do embasamento exposto nas bordas, ou seja, de rochas do Complexo Atuba e do Grupo Açungui, como apontado por estudo de proveniência de Machado et al. (2012).

Quanto à maturidade, predominam sedimentos imaturos composicional e texturalmente. Essas características podem ser indicativas de rápida deposição e/ou pouco transporte, possivelmente associada à tectônica característica da bacia com criação de espaço de acumulação em período relativamente curto. Além disso, sistemas fluviais distributivos têm padrão agradacional predominante, contribuindo para a preservação dos minerais mais instáveis. Também podem ser aventados como fatores que contribuíram para tal imaturidade a geração, o transporte e a deposição de sedimentos em ambiente com intemperismo químico brando evidenciado pela presença de matriz e argilas expansivas e pelo desenvolvimento de calcretes.

Processos atuais de intemperismo e pedogênese atuantes sobre os sedimentos expostos seriam responsáveis, assim como descrito por Bigarella e Salamuni (1962), pela cor das argilas em tons avermelhados no topo do afloramento. Análises químicas realizadas por Kormann (2002) indicaram passagem de esmectita para caulinita (neoformação), concentração de sílica e lixiviação dos elementos maiores nas argilas avermelhadas, assim como ocorrência de illita, atribuída ao intemperismo de feldspatos.

\section{Calcretes}

A cimentação carbonática descrita tem gênese associada à acumulação de carbonatos próxima à superfície, por influência de processos de desenvolvimento de solo (calcrete pedogenético) ou variações e saturação do nível freático (calcrete freático). As duas formas de desenvolvimento de calcretes podem formar perfis similares, que apresentam texturas nodular, laminar e maciço/crosta dura (Alonso-Zarza e Wright, 2010).

Nas seções estudadas, os intervalos nodulares e laminares estão associados às fácies mais finas, com predomínio de lamas e algumas camadas de areias (SG2 e SG3). Provavelmente, formaram-se em partes mais calmas do ambiente deposicional, contexto de menor energia e taxa de sedimentação, em que haveria condições adequadas para o desenvolvimento de vegetação, mesmo que temporariamente. Ali se daria a formação de perfis imaturos/pouco evoluídos de solos e a fixação do carbonato de cálcio induzida por processos biológicos. A ocorrência de rizocreções e icnofósseis nessas fácies ratifica a hipótese da origem edáfica na formação desses intervalos de calcretes.

Já os calcretes de textura maciça, ou dolocretes, por sua constituição em parte dolomítica, são encontrados na forma de estratos métricos associados às fácies mais arenosas.
Tais camadas são compostas por carbonato de textura micrítica sustentando componentes siliciclásticos, com cristais maiores de forma romboédrica envolvendo os grãos. Essas são características da microtextura do tipo alfa (Wright, 1990), que, com as feições macroscópicas, indicam ser calcretes de origem freática, conforme descrito por Alonso-Zarza e Wright (2010). Essas camadas são encontradas próximas ao topo do embasamento, que poderia ter atuado como barreira para circulação da água e contribuído para a concentração de íons e a precipitação dos carbonatos nos estratos mais porosos e permeáveis dos sedimentos. Esse tipo de calcrete também é encontrado como fragmentos retrabalhados constituindo parte do arcabouço em fácies arenosas e cascalhosas, indicando contemporaneidade entre a formação e o retrabalhamento associado à sedimentação da unidade.

\section{Neoestratótipo}

Ao descrever os sedimentos que preencheram a Bacia de Curitiba, Bigarella e Salamuni (1962) indicaram o afloramento localizado no cruzamento da atual BR $476 \mathrm{com}$ a Avenida Senador Salgado Filho, no bairro Guabirotuba, como o local com as melhores exposições dos sedimentos (sic, Figura 11A). A unidade recebeu, assim, a designação de Formação Guabirotuba, homônima ao bairro. Todavia, a urbanização encobriu a antiga exposição, tornando-a inacessível para observação devido às contenções de talude e à cobertura vegetal que garantem a segurança da rodovia.

Entretanto, o Geossítio Bacia Sedimentar de Curitiba, local dos estudos aqui relatados, constitui exposição representativa da unidade, formada por associações litofaciológicas similares às descritas como seção original por Bigarella e Salamuni (1962), ao definirem a unidade. No novo local, aqui designado como neoestratótipo para a Formação Guabirotuba, observam-se intercalações de lamas e areias, com intervalos de cimentação carbonática (calcretes, originalmente descritos como margas), limite inferior em contato com o embasamento (superfície de não conformidade). A única diferença recai sobre a inversão da relação lamas/areia, por causa da diferença dos afloramentos em relação à posição na bacia e ao seu preenchimento (Figura 11B).

O estabelecimento da nova seção-tipo no Geossítio Bacia Sedimentar de Curitiba possibilita, ainda, atualizar sua representatividade quanto ao grau de conhecimento sobre a bacia paleógena, por ser o local de importante ocorrência fossilífera da Fauna Guabirotuba. Ademais, a localização do estratótipo da Formação Guabirotuba no interior de uma ARIE, protegida por lei, auxiliará na preservação da seção-tipo e constitui garantia de que será um local privilegiado para pesquisas, atividades didáticas e de difusão científica, enfim, de aplicação dos modernos preceitos de geoconservação. 
A

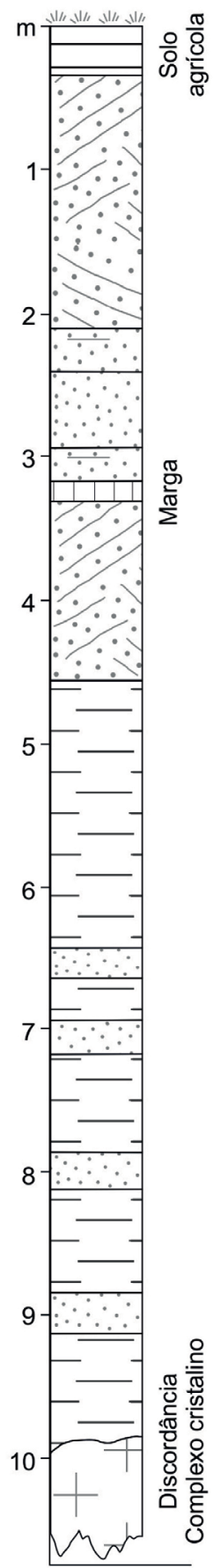

B

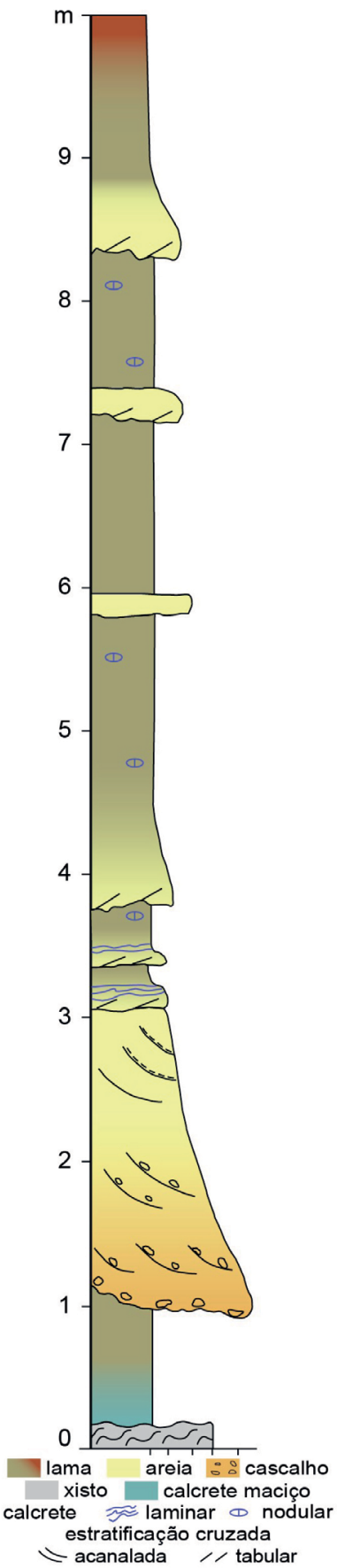

Figura 11. Formação Guabirotuba: (A) Perfil descrito no bairro Guabirotuba por Bigarella e Salamuni (1962), redesenhado. As texturas, mantidas como no original, seguem padrão gráfico usual para os intervalos granulométricos e estruturas sedimentares. A descrição detalhada do perfil pode ser encontrada no artigo supracitado; (B) perfil composto, definido como nova seção-tipo para a Formação Guabirotuba, descrito no geossítio Bacia Sedimentar de Curitiba na Cidade Industrial de Curitiba.

\section{CONCLUSÃO}

$\mathrm{Na}$ área designada Geossítio Bacia Sedimentar de Curitiba foram reconhecidas duas associações de fácies, compostas por oito fácies sedimentares e seis elementos arquitetônicos correspondentes a depósitos de preenchimento de canal e de planície de inundação, atribuídas a sistemas fluviais distributários.

Os depósitos da porção proximal do sistema são constituídos de barras arenosas e cascalhosas preenchendo canais de rios entrelaçados, parcialmente sobrepostos e lateralmente amalgamados, formadas pelo crescimento e pela migração de dunas subaquosas. Já a porção distal é formada por espessas camadas de lama intercaladas com delgadas lentes e lençóis de areia, essas correspondentes a depósitos de fluxos desconfinados na planície de inundação.

A imaturidade composicional e textural dos sedimentos resulta de fatores climáticos, com intemperismo químico brando resultando na formação de argilas expansivas e preservação de parte dos feldspatos, e deposicionais, pouco transporte e rápida deposição, característicos de bacias do tipo rifte, com rápida criação de espaço e proximidade de áreas-fonte soerguidas.

As texturas macro e microscópicas dos calcretes permitiram separar sua gênese em: pedogenética, para os horizontes laminares e nodulares associados a sedimentos de granulação fina, e freática, para os estratos maciços em sedimentos de granulação mais grossa, geralmente próximos ao contato com o embasamento. Além disso, algumas deformações, sobretudo da estratificação, estão associadas com a ocorrência da cimentação carbonática concentrada em núcleos, que em parte engloba as estruturas, mas localmente as deforma no processo de desenvolvimento dos horizontes de crostas duras.

Fraturas e falhas de pequeno deslocamento seccionando os depósitos, às vezes em continuidade com estruturas tectônicas do embasamento, atestam a ocorrência de atividades neotectônicas, já identificadas para a bacia. Ocasionalmente, essas estruturas são evidenciadas pelo preenchimento por carbonatos remobilizados dos intervalos de calcrete. Não se exclui a possibilidade de deformações singenéticas associadas à acomodação gravitacional ou a desestabilizações, pois a tectônica também contribui para a formação dessas descontinuidades.

As características composicionais e texturais descritas, representativas da Formação Guabirotuba, aliadas ao fato de abrigarem novas e importantes ocorrências fossilíferas, assim como a localização protegida em unidade de conservação, permitem propor, aqui, a designação formal do Geossítio Bacia Sedimentar de Curitiba como área-tipo da Formação Guabirotuba, com a composição de seus cortes caracterizando a nova seção-tipo ou neoestratótipo da unidade. 


\section{AGRADECIMENTOS}

Agradecimentos à Coordenação de Aperfeiçoamento de Pessoal de Nível Superior (CAPES), a concessão de bolsa de estudos à autora, para o desenvolvimento da pesquisa, e ao Conselho Nacional de Desenvolvimento Científico e Tecnológico (CNPq), a bolsa de produtividade em pesquisa ao segundo autor. Agradecimentos também são devidos aos amigos que auxiliaram nos trabalhos de campo, ao Laboratório de Minerais e Rochas da Universidade Federal do Paraná (Lamir), pela confecção de seções delgadas e análises de difração de raios X, assim como aos relatores, pelas sugestões que fizeram para aprimorar este artigo.

\section{REFERÊNCIAS}

Almeida, F. F. M. (1976). The system of continental rifts bordering the Santos Basin, Brazil. Anais da Academia Brasileira de Ciências, 48(Supl.), 15-26.

Alonso-Zarza, A. M., Wright, V. P. (2010). Calcretes. In: A. M. Alonso-Zarza, L. H. Tanner (Eds.), Developments in Sedimentology (v. 61, p. 225-267). Amsterdã: Elsevier. https://doi.org/10.1016/S0070-4571(09)06105-6

Azevedo, F. F. (1981). Thecamoebianas e organófitas na Formação Guabirotuba. III Simpósio Regional de Geologia, 2, 226-242. Curitiba: SBG.

Becker, R. D. (1982). Distribuição dos sedimentos cenozóicos na Região Metropolitana de Curitiba e sua relação com a estrutura geológica e morfológica regional. Tese (Doutorado). Porto Alegre: Pós-graduação em Geociências, UFRGS.

Bigarella, J. J., Salamuni, R. (1958). Consideração sobre o paleoclima da bacia de Curitiba. Boletim do Instituto de História Natural, 1, 1-10.

Bigarella, J. J., Salamuni, R. (1959). Notas complementares à planta geológica da cidade de Curitiba e arredores. Boletim do Instituto de Biologia e Pesquisas Tecnológicas, 40, 1-14.

Bigarella, J. J., Salamuni, R. (1962). Caracteres texturais dos sedimentos da Bacia de Curitiba. Boletim da Universidade Federal do Paraná, 7, 1-164.

Bigarella, J. J., Salamuni, R., Ab’sáber, A. N. (1961). Origem e ambiente de deposição da Bacia de Curitiba. Boletim Paranaense de Geografia, 4/5, 71-81.

Carvalho, P. F. (1934). Geologia do município de Curitiba. Boletim DNPM-SGM, 82, 1-21.
Coimbra, A. M., Riccomini, C. (1985). Considerações paleoambientais sobre as ocorrências de caliche nas bacias de Curitiba (PR), Taubaté (SP), Resende (RJ). Anais da Academia Brasileira de Ciências, 57(4), 517-518. Disponível em: <http://memoria.bn.br/DocReader/158119/28047>. Acesso em: 19 jun. 2020.

Coimbra, A. M., Riccomini, C., Sant'anna, L. G., Valarelli, J. V. (1996). Bacia de Curitiba: estratigrafia e correlações regionais. XXXIX Congresso Brasileiro de Geologia, 1, 135-137. Salvador: SBG.

Companhia de Pesquisa de Recursos Minerais (CPRM). (2004). Unidades litoestratigráficas 1:1.000.000 2004 formato shapefile. Disponível em: $<$ http://geowebapp.cprm. gov.br>. Acesso em: 12 jun. 2020.

Coutinho, J. M. V. (1955). Lantanita de Curitiba, Paraná. Boletim da Faculdade de Filosofia, Ciências e Letras da Universidade de São Paulo, (13), 119-126. https://doi. org/10.11606/bmffclusp.v0i13.121468

Cunha, P. V. C. (2011). Gênese de calcretes da Formação Guabirotuba, Bacia de Curitiba, Paraná. Dissertação (Mestrado). Curitiba: Pós-graduação em Geologia, UFPR. Disponível em: $<$ http://hdl.handle.net/1884/26941>. Acesso em: 12 jun. 2020.

Cunha, R. F. (2016). Contexto Paleoambiental e Tafonomia da Assembléia Fóssil da Formação Guabirotuba, Bacia De Curitiba, Paraná. Dissertação (Mestrado). Curitiba: Pós-Graduação em Geologia, UFPR. Disponível em: $<$ http://hdl.handle.net/1884/43406>. Acesso em: 12 jun. 2020 .

Environmental Systems Research Institute (ESRI). (2020). Basemap World Imagery. Earthstar Geographics TerraColor imagery of Earth. Disponível em: <goto.arcgisonline.com/ maps/World_Imagery>. Acesso em: 12 jun. 2020.

Fernandes, L. A., Lima, F. F., Sedor, F. A., Vargas, J. C., Dias, E. V. (2016). Geossítio Bacia Sedimentar de Curitiba: conservação de patrimônio geológico de excepcional relevância científica em área urbana. XLVIII Congresso Brasileiro de Geologia. Porto Alegre: SBG. Disponível em: $<$ http://cbg2017anais.siteoficial.ws/anais48cbgcompleto. pdf $>$. Acesso em: 12 jun. 2020.

Fisher, J. A., Nichols, G. J., Waltham, D. A. (2007) Unconfined flow deposits in distal sectors of fluvial distributary systems: Examples from the Miocene Luna and Huesca Systems, northern Spain. Sedimentary Geology, 195(1-2), 55-73. https://doi.org/10.1016/j.sedgeo.2006.07.005 
Garcia, M. J., Lima, F. M., Fernandes, L. A., Melo, M. S., Dino, R., Antonioli, L., Menezes, J. B. (2013). Idade e palinologia da Formação Guabirotuba, Bacia de Curitiba, PR, Brasil. XXIII Congresso Brasileiro de Paleontologia/I Simpósio de Paleontologia Brasil-Portugal, 1, 125. Gramado: SBP.

Instituto Brasileiro de Geografia e Estatística (IBGE). (2015). Municipios (41MUE250GC_SIR), UFs (BRUFE250GC_ $S I R$ ) formato shapefile. Download em: <mapas.ibge.gov.br/ bases-e-referenciais/bases-cartograficas/malhas-digitais $>$. Acesso em: 12 jun. 2020.

Kormann, A. C. M. (2002). Comportamento geomecânico da Formação Guabirotuba: estudos de campo e laboratório. Tese (Doutorado). São Paulo: Escola Politécnica, USP. https://doi.org/10.11606/T.3.2002.tde-20072009-092526

Liccardo, A., Weinschütz, L. C. (2010). Registro inédito de fósseis de vertebrados na bacia sedimentar de Curitiba. Revista Brasileira de Geociências, 40(3), 330-338. https:// doi.org/10.25249/0375-7536.2010403330338

Lima, F. F., Sedor, F. A., Fernandes, L. A., Vargas, G. C., Dias, E. V., Silva, D. D. (2015). Guabirotuba geosite, Curitiba Basin, Brazil: exceptional geological heritage at risk in an urban area. VIII International ProGEO Symposium, 86-87. Reykjavík: ProGEO.

Lima, F. M., Fernandes, L. A., Melo, M. S., Góes, A. M., Machado, D. A. M. (2013). Faciologia e contexto deposicional da Formação Guabirotuba, Bacia de Curitiba (PR). Brazilian Journal of Geology, 43(1), 168-184. http://dx.doi.org/10.5327/ Z2317-48892013000100014

Maack, R. (1947). Breves Notícias Sobre a Geologia dos Estados do Paraná e Santa Catarina. Arquivos de Biologia e Tecnologia, 2, 63-154.

Machado, D. A. M., Fernandes, L. A., Góes, A. M., Mesquita, M. J., Lima, F. M. (2012). Proveniência de sedimentos da Bacia de Curitiba por estudos de minerais pesados. Revista Brasileira de Geociências, 42(3), 563-572. http://dx.doi. org/10.5327/Z0375-75362012000300010

Miall, A. D. (1977). A review of the braided-river depositional environment. Earth-Science Reviews, 13(1), 1-62. https:// doi.org/10.1016/0012-8252(77)90055-1

Miall, A. D. (1985). Architectural-element analysis: A new method of facies analysis applied to fluvial deposits. Earth Science Reviews, 22(4), 261-308. https://doi. org/10.1016/0012-8252(85)90001-7
Miall,A. D. (2006). The geology of fluvial deposits: sedimentary facies, basin analysis, and petroleum geology. 4. ed. Berlin: Springer-Verlag. https://doi.org/10.1007/978-3-662-03237-4

Nichols, G. J., Fisher, J. A. (2007). Processes, facies and architecture of fluvial distributary system deposits. Sedimentary Geology, 195(1-2), 75-90. https://doi. org/10.1016/j.sedgeo.2006.07.004

Oliveira, A. I., Leonardos, O. H. (1943). Geologia do Brasil. Rio de Janeiro: Serviço de Informação Agrícola/Ministério da Agricultura.

Oliveira, E. P. (1927). Geologia e recursos minerais do Estado do Paraná. Rio de Janeiro: Serviço Geológico e Mineralógico do Brasil.

Riccomini, C. (1989). O rift continental do sudeste do Brasil. Tese (Doutorado). São Paulo: Instituto de Geociências, USP. https://doi.org/10.11606/T.44.1990. tde-18032013-105507

Riccomini, C., Sant'anna, L. G., Ferrari, A. L. (2004). Evolução Geológica do Rift Continental do Sudeste do Brasil. In: V. Mantesso Neto, A. Bartorelli, C. D. R. Carneiro, B. B. B. Neves (Eds.). Geologia do Continente Sul-Americano: evolução da obra de Fernando Flávio Marques de Almeida, p. 383-405. São Paulo: Beca. Disponível em: <https:// www.researchgate.net/publication/281589766_Evolucao_ geologica_do_rift_continental_do_sudeste_do_Brasil_2004>. Acesso em: 12 jun. 2020.

Salamuni, E., Ebert, H. D., Borges, M. S., Hasui, Y., Costa, J. B. S., Salamuni, R. (2003). Tectonics and sedimentation in the Curitiba Basin, south of Brazil. Journal of South American Earth Sciences, 15(8), 901-910. https://doi. org/10.1016/S0895-9811(03)00013-0

Salamuni, E., Ebert, H. D., Hasui, Y. (2004). Morfotectônica da Bacia Sedimentar de Curitiba. Revista Brasileira de Geociências, 34(4), 469-478.

Salamuni, E., Salamuni, R., Ebert, H. D. (1999). Contribuição à geologia da Bacia Sedimentar de Curitiba. Boletim Paranaense de Geociências, (47), 123-142.

Sedor, F. A., Dias, E. V., Fernandes, L. A., Lima, F. F., Vargas, J. C., Silva, D. D. (2017a). Geossítio Bacia sedimentar de Curitiba (Formação Guabirotuba): características, importância paleontológica e conservação. IV Simpósio Brasileiro de Patrimônio Geológico \& II Encontro Luso-Brasileiro de Patrimônio Geomorfológico e Geoconservação, 152-156. Ponta Grossa. 
Sedor, F. A., Oliveira, E. V., Silva, D. D., Fernandes, L. A., Cunha, R. F., Ribeiro, A. M., Dias, E. V. (2014). A new South American Paleogene fauna, Guabirotuba Formation (Curitiba, Paraná State, south of Brazil). IV International Palaeontological Congress, 614. Mendoza.

Sedor, F. A., Oliveira, E. V., Silva, D. D., Fernandes, L. A., Cunha, R. F., Ribeiro, A. M., Dias, E. V. (2017b). A New South American Paleogene Land Mammal Fauna, Guabirotuba Formation (Southern Brazil). Journal of Mammalian Evolution, 24, 39-55. https://doi.org/10.1007/s10914-016-9364-7

Siemiradzki, J. (1898). Geologische Reisebeobachtungen in Süd-Brasilien. Kaiserlich-königlichen hof-und Staatsdruckerei, 107(1), 23-40.

Siga Jr., O., Basei, M. A. S., Reis Neto, J. M., Machiavelli, A., Harara, O. M. (1995). O Complexo Atuba: um cinturão Paleoproterozóico intensamente retrabalhado no Neoproterozóico. Boletim IG-USP. Série Científica, 26, 69-98. https://doi.org/10.11606/issn.2316-8986.v26i0p69-98

Walker, R. G. (1992). Facies, facies models and modern stratigraphic concepts. In: R. G. Walker, N. P. James (Eds.),
Facies models: response to sea level changes, p. 1-14. Stittsville: Geological Association of Canada.

Weissmann, G. S., Hartley, A. J., Nichols, G. J., Scuderi, L. A., Olson, M., Buehler, H., Banteah, R. (2010). Fluvial form in modern continental sedimentary basins: Distributive fluvial systems. Geology, 38(1), 39-42. https://doi.org/10.1130/ G30242.1

Weissmann, G. S., Hartley, A. J., Scuderi, L. A., Nichols, G. J., Owen, A., Wright, S., Felicia, A. L., Holland, F., Anaya, F. M. L. (2015). Fluvial geomorphic elements in modern sedimentary basins and their potential preservation in the rock record: A review. Geomorphology, 250, 187-219. https:// doi.org/10.1016/j.geomorph.2015.09.005

Wright, V. P. (1990). A micromorphological classification of fossil and recent calcic and petrocalcic microstructures. Developments in Soil Science, 19, 401-407. https://doi. org/10.1016/S0166-2481(08)70354-4

Zalán, P. V., Oliveira, J. A. B. (2005). Origem e evolução do Sistema de Riftes Cenozóicos do Sudeste do Brasil. Boletim de Geociências da Petrobras, 13(2), 269-300. 